\title{
A Taxonomy of Future Higher Thinking Skills
}

\author{
David PASSIG \\ School of Education, Bar-Ilan University \\ 52900 Ramat-Gan, Israel \\ e-mail: passig@mail.biu.ac.il
}

Received: February 2003

\begin{abstract}
Our future society will be different from that we have known in the last fifty years. Futurists foresee that in the near couple decades the world's community will traverse through a period of rapid technological innovations that will change the foundations of society as we used to know it (Tapscott, 1997; Wallace, 1999; Borgmann; 1999). Changes will engulf all aspects of life (Gleick, 1999). These changes will have great impact on society, work, culture and art. People will have to innovate or evaporate (Higgins, 1995). They will have to adapt continuously to never-ending permutations and engage in a never-ending adaptation.

It makes sense, therefore, to assume that the graduates of today's schooling will need a different set of cognitive and learning skills reflecting the profound change that they will encounter. This paper traces the basic nature of future society and proposes a relevant taxonomy of future cognitive skills that will provide our students with appropriate tools to succeed in the future. We have used Bloom's taxonomy as a working ground and expanded his categories to reflect the needs of the future. This paper suggests an additional cognitive category to add to our teaching procedures named melioration, which we believe, is not addressed in today's curriculum.
\end{abstract}

Key words: future, taxonomy, learning skills, cognition, knowledge, thinking skills, high intelligence, melioration.

\section{Introduction}

From time immemorial, every generation's role was to prepare its next generation to the future. However, the nature of the future we are facing today does not resemble futures that past generations have been confronting. The nature of the social, economical, industrial, and technological passages that our generation is facing will present our students with challenges that no past generation has encountered (Schwartz, 1999).

This should bring us, at the turn of the century, toward examining the cognitive proficiencies that our children will need to succeed in their adulthood lives.

Dealing with such an issue in itself will probably raise substantial skepticism from various disciplines. How do you conduct such an examination? What are your research methodologies and whether they insure the results indeed point to the skills that will be required from our graduates in the future?

It is unnecessary to point out that questions such as these are too convoluted to be treated in this framework. The methodological literature concerning future research methodologies is full with discussions of this nature (Kurian and Molitor, 1996). 
Nevertheless, we must emphasize that the research, part of which its results is reported here, does not suggest the results to be projections. We used content analysis as a methodology and looked at how a variety of authors in various knowledge domains, at present, reckon what learning and cognitive skills will be required from our schools' graduates in future social, technological, industrial, and economical environments.

For this purpose, we have grounded our research on the tradition of cognitive taxonomies developed in the course of the recent half century. We have selected Bloom's taxonomy since it is a well-known taxonomy among educators worldwide. We have assumed to be able to modify it to reflect future thinking necessities of future adults.

Moreover, our research suggests that an additional cognitive proficiency should be reflected in today's curriculum. Melioration reflects a critical cognitive activity in future societies. In this paper we define this skill, and discuss its characteristics and importance.

Obviously, the results of this research should be examined in light of the subjective perspective of the literature we have analyzed to date. We do not aim to point out future cognitive skills. We do not have, in our present stage, the ability to estimate these skills accurately. All we can do is to estimate how we see future needs today. Thus, the goal of this study is to present these evaluations to those of us developing curricular materials.

\section{The Knowledge Age}

In the course of the 1990's, various cultures have already begun to experience a wave of changes characterized by a profound transition from the socio-economic state of trading information as a commodity into a global state of manufacturing knowledge (Perelman, 1992; Kennedy, 1993). In this "knowledge-age" it is not sufficient to have skills of accessing information in order to achieve a relative advantage. The knowledge-age indicates that there is a need of unique cognitive skills in order to achieve a successful implementation of information in real time. Those who will have the skills of collecting information in real time, as well as the ability to analyze, classify, and organize it, will be those to achieve a social, cultural and economical advantage.

Most of the intellectual activity will be to amplify the value of available information. Thus, education in this age will have to be focused on knowledge - a successful implementation of information under the right circumstance and at the right time. The knowledge-age acknowledges the fact that shifts at the information overflow will be accelerated, and that the main role of people will be to add value to the exchange of information (Harkins, 1992; O’Dell, 1998).

In past generations the insulated elite was requested to manage information of large complexity and capacity in order to guide humanity in its efforts to improve life conditions. These efforts took place in relatively small communities. On the other hand, in a knowledge-age, information in great quantity could be available to many, who will globally compete for its use. In order for societies to succeed in guiding their efforts to improve conditions effectively, they will need a significant amount of working teams that will be able to generate personal and/or collective, ethnic, and cultural added value (Passig, 1996). 


\section{The Nature of Future Knowledge}

Knowledge is the product of information processing. Thus, future knowledge will have local and personal characterization. Knowledge as a product will reflect where and when it has been processed. To produce knowledge, societies will have to develop procedures that filter information and blend it with religious values, tradition, customs, and even cultural or political preferences. Successful future societies will have to alternate their focal efforts from negotiating information into negotiating exclusive and local values, and retail them among different cultures.

\section{The Research Procedure}

In preparing this study we have used Content Analysis as our research methodology. After deciding upon the research technique, we faced an unsolved dilemma. We had to define the depth and range of the literature we were about to cover in order to grant our results reasonable validity. Eventually, we did not rule out this question, since we believe that such a research has to be extensive and continuous. Thus, we intend to conduct this study in several stages. This paper summarizes the results of the first stage of a continuous study in which we are engaged. In this first stage, we examined about 300 books from various future fields of interest as being categorized by the World Future Society (www. wfs. org). We selected from categories such as future technology, future economy, future life style, etc., a handful of representing recent publications (a complete list of publications can be found in Passig 1998).

\section{Theoretical Framework}

We assumed we would be able to find in the literature, key words and phrases depicting future and most needed skills. In order to avoid formulation of lists concerning skills with no theoretical base, we had to choose a proper theoretical framework that will guide our efforts and consolidate our findings. Thus, we have examined various theories such as Bloom's taxonomy of cognitive skills (Bloom, 1956), Gardner's intelligences (1983, 1999), and Sterenberg's thinking styles (Sterenberg, 1997). Finally, we have decided that to simplify the editing process of our findings, it would be better if we work out of the most familiar theoretical framework - Bloom's cognitive taxonomy.

Many examined the nature of thinking in order to improve it and develop efficient learning strategies. During the years, different and various concepts were developed such as: high-thinking, productive thinking, interactive thinking, etc. However, Bloom and his colleagues (1956), were among the first to suggest a taxonomy of thinking constituents. Its essence was a layout of goals concerning fostering a type of thinking higher than remembering and understanding. Bloom suggested a hierarchy of six thinking levels/categories: knowledge, comprehension, application, analysis, synthesis, and evaluation.

Over the years, many researchers criticized Bloom's taxonomy (Nelson, 1981; Ennis, 1981; Seddon, 1978 and others). Ennis 1981, for example, claimed that the three highest levels in Bloom's taxonomy are thinking skills of a higher order. They supply too thin 
guidance for training, and they are not escorted with criteria for teaching evaluation. Many criticized the fact that there is an abundance of terms and definitions in the domains of psychology and education, and offered that instead of undertaking one term or another, it is better to adapt the use of the ultra-term Higher Thinking Skills. This term is not exclusive to one type of thinking or another; instead, it generally emphasizes the contrast between lower order thinking skills (memorizing, remembering, etc.) and thinking skills, which require more complex mental functions.

Nevertheless, since its publication (Bloom, 1956), the taxonomy has endured criticism and has developed in various directions. It was not feasible at the initial stage of this study to consider the variety of nuances that are attached to Bloom's taxonomy. However, a more comprehensive discussion in a wider framework is needed in the future.

\section{Bloom's Taxonomy of Cognitive Skills}

Bloom's taxonomy was meant to achieve two main objectives: curricular planning and achievement tests. His taxonomy offered the possibility to examine achievements in planed teaching procedures with regard with their behavioral goals. The following (Table 1) is a short version of Bloom's taxonomy and its behavioral objectives.

Table 1

Bloom's Taxonomy: definitions and behavioral objectives

\begin{tabular}{|c|c|c|}
\hline Categories & Definitions & Behavioral objectives \\
\hline Knowledge & $\begin{array}{l}\text { Any teaching purpose that needs just } \\
\text { memorization. }\end{array}$ & $\begin{array}{l}\text { Defines, outlines, identifies, titles, classi- } \\
\text { fies, notes, chooses, attaches, memorizes. }\end{array}$ \\
\hline Comprehension & $\begin{array}{l}\text { A thinking process in which a message is } \\
\text { changing form. }\end{array}$ & $\begin{array}{l}\text { Reverses. defends, discerns, assesses, ex- } \\
\text { plains, inclusion, expands, exemplifies, } \\
\text { concludes, rewrites, summarizes, trans- } \\
\text { lates, changes, supplements. }\end{array}$ \\
\hline Application & $\begin{array}{l}\text { The ability to implement rules, princi- } \\
\text { ples, information, assumptions, theories, } \\
\text { or other abstractions for new and real si- } \\
\text { tuations. }\end{array}$ & $\begin{array}{l}\text { Calculates, demonstrates, discovers, com- } \\
\text { prehends, improves, activates, predicts, un- } \\
\text { derstands, produces, relates to, divides into } \\
\text { sections, develops, includes, attributes. }\end{array}$ \\
\hline Analysis & $\begin{array}{l}\text { A thorough study to comprehend the } \\
\text { structure of the learned content, its formal } \\
\text { and logic way of organization, in order to } \\
\text { detect the elements, outlooks, and meth- } \\
\text { ods this content is based upon. }\end{array}$ & $\begin{array}{l}\text { Divides into sections, graphically de- } \\
\text { scribes, classifies, distinguishes, identifies, } \\
\text { concludes, emphasizes, connects, catego- } \\
\text { rizes, confronts, compares. }\end{array}$ \\
\hline Synthesis & $\begin{array}{l}\text { Establishing a whole new creation by } \\
\text { combination of ideas from different } \\
\text { sources, in a way that formats and molds } \\
\text { will be created, and will stand at the basis } \\
\text { of the new creation. }\end{array}$ & $\begin{array}{l}\text { Combines and adds, creates, prepares, } \\
\text { plans, improves, organizes, rearranges, re- } \\
\text { structures, replicates, offers, tells, deve- } \\
\text { lops. }\end{array}$ \\
\hline Evaluation & $\begin{array}{l}\text { Judging the values in the ideas through } \\
\text { use of standards of estimations, that will } \\
\text { determine the accuracy level, purposeful- } \\
\text { ness and practicality of the details. }\end{array}$ & $\begin{array}{l}\text { Evaluates, compares, concludes, criticizes, } \\
\text { separates, attributes, summarizes, sup- } \\
\text { ports, judges, claims, confronts, sets a } \\
\text { norm. }\end{array}$ \\
\hline
\end{tabular}




\section{Future Thinking Skills}

Using content analysis, we have researched the list of publications assembled from the World Future Society (www.wfs.org) and examined key words and phrases depicting the possible nature of future thinking and learning skills. We then consolidated, the large amount of findings into sub-categories along side with examples from the literature being researched (Passig, 1998; 2001). The following (Table 2) is a condensed version of our findings organized under the same categories developed by Bloom and his colleagues. The following thinking and learning skills derive out of the various challenges that human society faces in the short-term (5-10 years) and the median term futures (10-25 years).

Amazingly, or not, the driving forces behind these challenges are mostly information technologies. The literature we have examined is a fascinating evidence that there exists today a consensus across the board that Information Technology (IT) is the pivotal force behind most permutations we are about to encounter on most realms of future reality. Moreover, the depth and pace of connectedness that IT is about to deliver, we believe, is what will make IT the primary driving force to societal upheaval.

We suppose, however, that IT itself is the key that can help us deliver to our students the skills needed to succeed and to ride the transitions ahead. However, even if everyone does not agree with this statement, surely we need to prepare our next generation to undertake the kind of challenges that IT will introduce to society, by providing our students with meta-cognitive tools for using IT. We suggest, therefore, that the following skills be considered at least as such. It is evident from the literature we have examined that people who will master these skills will have great advantages over others.

Nonetheless, the following suggested list of skills can be considered as a reminder that intelligence itself is evolutionary, and that we cannot rely solely on the way we defined cognitive skills half a century ago. This list of skills, however, cannot replace other lists or curricular objectives. It merely aims to enlarge existing definitions of thinking skills. It might be considered just as a proactive approach to the evolution of intelligence, since we really cannot predict where human cognition is headed.

\section{Melioration}

In summarizing our findings, we found that out of the literature stems a new category that could stand on its own. We struggled to choose a name that will support its independence, and chose the term Melioration. Finally, although the category could be a composition of several skills, it seemed to us that we should set it separately, mainly since it points to a type of cognitive skill with which we have not dealt with in our curriculum so far. Especially since, according to the literature that we have examined, this skill is becoming increasingly important in future thinking procedures. This thinking skill has a great many of the characteristics of future intelligence. Following is its definition, its behavioral terms, which stem from it, and the key words by which it is characterized (Table 3).

We were also able to distinguish between two different kinds of melioration. In them we identified six clearly defined stages. The two principle kinds of melioration of ideas are: 
Table 2

Future cognitive learning taxonomy

\begin{tabular}{|c|c|c|c|}
\hline Categories & Definition & Behavioral objectives & Key words \\
\hline Knowledge & $\begin{array}{l}\text { To achieve successful application of } \\
\text { information in real time. }\end{array}$ & $\begin{array}{l}\text { To know where to find } \\
\text { details; to master search } \\
\text { strategies; to develop new } \\
\text { symbols in a super-sym- } \\
\text { bolic society; to develop } \\
\text { conventions. }\end{array}$ & $\begin{array}{l}\text { To locate; to know } \\
\text { where to search; to fil- } \\
\text { ter; to be updated; to } \\
\text { leave out; to develop. }\end{array}$ \\
\hline Comprehension & $\begin{array}{l}\text { Multi-facet comprehension of a cer- } \\
\text { tain information; setting up frag- } \\
\text { ments of information in various } \\
\text { ways, when each composition has a } \\
\text { different meaning. }\end{array}$ & $\begin{array}{l}\text { To expand existing mo- } \\
\text { dels of thinking; to set the } \\
\text { way of thinking up in a } \\
\text { wider framework; to in- } \\
\text { vent symbols for concrete } \\
\text { elements and to trade in } \\
\text { these symbols; to create } \\
\text { inferences \& analogies in } \\
\text { various ways. }\end{array}$ & $\begin{array}{l}\text { To expand; to set up in } \\
\text { a wider framework; to } \\
\text { invent symbols; to rel- } \\
\text { atively connect. }\end{array}$ \\
\hline Application & $\begin{array}{l}\text { The ability to produce new ideas } \\
\text { out of an old idea, in order to } \\
\text { implement relevant information in } \\
\text { real time and in different variations. } \\
\text { To create new meaning for new } \\
\text { symbols, new meaning for existing } \\
\text { symbols, and to create a new sym- } \\
\text { bol for an existing meaning. }\end{array}$ & $\begin{array}{l}\text { Use of codes and symbols } \\
\text { - new and old; change of } \\
\text { old codes and symbols. }\end{array}$ & $\begin{array}{l}\text { To initiate change; to } \\
\text { be flexible; to decide; } \\
\text { to reorganize. }\end{array}$ \\
\hline Analysis & $\begin{array}{l}\text { Dividing a unit of information } \\
\text { into its components, and structur- } \\
\text { ing varied and different relation- } \\
\text { ships, even opposed to the unit's } \\
\text { components. To choose from the } \\
\text { ocean of dynamic information, out } \\
\text { of personal/cultural/ ethnic judg- } \\
\text { mental values. To set fragments of } \\
\text { information up in a multi dimen- } \\
\text { sional spatial structure. To simulate } \\
\text { various implications to various rela- } \\
\text { tions, and simulation of various per- } \\
\text { spectives in the multi dimensional } \\
\text { space. }\end{array}$ & $\begin{array}{l}\text { To create relations; to dis- } \\
\text { tinguish between relations; } \\
\text { to analyze pieces of in- } \\
\text { formation in various ways; } \\
\text { to evaluate reliability of } \\
\text { information and set frag- } \\
\text { ments of information up in } \\
\text { different relations putting } \\
\text { in mind that the relations } \\
\text { will be given to the influ- } \\
\text { ences of time space and } \\
\text { personal intuition. }\end{array}$ & $\begin{array}{l}\text { Relevant choice, sub- } \\
\text { tlety in a personal } \\
\text { prism, disassembling } \\
\text { and structuring rela- } \\
\text { tions between frag- } \\
\text { ments of information. }\end{array}$ \\
\hline Synthesis & $\begin{array}{l}\text { Creating various combinations with } \\
\text { different meanings out of given } \\
\text { units of information. }\end{array}$ & $\begin{array}{l}\text { To locate a separate ele- } \\
\text { ment out of the pieces } \\
\text { of information that it was } \\
\text { taken from, in order to } \\
\text { grant it a new meaning. }\end{array}$ & $\begin{array}{l}\text { To identify; to con- } \\
\text { nect. }\end{array}$ \\
\hline Evaluation & $\begin{array}{l}\text { To know how to choose suitable cri- } \\
\text { teria and develop new criteria in or- } \\
\text { der to develop an evaluation that } \\
\text { will be useful for the continuation } \\
\text { of learning process. Evaluating the } \\
\text { concealed as well. }\end{array}$ & $\begin{array}{l}\text { To evaluate qualitatively } \\
\text { and quantitatively; to fo- } \\
\text { cus and to connect be- } \\
\text { tween the overall relevant } \\
\text { items. }\end{array}$ & $\begin{array}{l}\text { Disqualifies; proces- } \\
\text { ses; checks; confronts. }\end{array}$ \\
\hline
\end{tabular}


Table 3

The definition of the skill of melioration

\begin{tabular}{|c|c|c|c|}
\hline The 7th Category & Definition & Behavioral terms & Key words \\
\hline Melioration & $\begin{array}{l}\text { The skill of selecting the } \\
\text { appropriate amalgam of } \\
\text { information and applying } \\
\text { it to a solution of prob- } \\
\text { lems in situations, which } \\
\text { arise at different times and } \\
\text { places, thereby meliora- } \\
\text { ting the amalgam. }\end{array}$ & $\begin{array}{l}\text { 1. Adaptation: To create an in- } \\
\text { novative product by making } \\
\text { a personal cognitive con- } \\
\text { nection between two areas, } \\
\text { which appear to be distant, } \\
\text { one from the other. } \\
\text { 2. Connotation: The personal } \\
\text { significance, which a par- } \\
\text { ticular person attaches to a } \\
\text { particular piece of informa- } \\
\text { tion of which he is aware. } \\
\text { 3. The power to forget. }\end{array}$ & $\begin{array}{l}\text { Adaptation } \\
\text { Connotation } \\
\text { Simultaneity }\end{array}$ \\
\hline
\end{tabular}

A. The melioration of information, concepts, ideas, and insights

B. The melioration of tools and technologies.

We found six stages in the meliorating of information, concepts, ideas, and insights: Original intention, occasionally retrospective intention, process, result, evaluation, and continuity (Table 4).

In order to meliorate information, one needs to embed in his/her thinking procedures ethnic, cultural, traditional, and personal connotations. The following example can

Table 4

Six cognitive stages in the melioration of ideas

\begin{tabular}{|c|c|c|}
\hline \multicolumn{2}{|c|}{ Stages } & \multirow{2}{*}{$\begin{array}{l}\text { Melioration of concepts } \\
\text { The melioration of concepts or tools is planned in advance }\end{array}$} \\
\hline 1. & $\begin{array}{l}\text { Initial intention to me- } \\
\text { liorate an idea }\end{array}$ & \\
\hline 2. & $\begin{array}{l}\text { Retrospective inten- } \\
\text { tion }\end{array}$ & $\begin{array}{l}\text { In the content analysis of both kinds of melioration, intentions were occa- } \\
\text { sionally identified which appeared only after the melioration, i.e., the melio- } \\
\text { ration wasn't planned in advance. }\end{array}$ \\
\hline 3. & $\begin{array}{l}\text { The process of melio- } \\
\text { rating an idea }\end{array}$ & $\begin{array}{l}\text { When analysis is continued over an extended period of time, it exists in both } \\
\text { kinds of melioration. }\end{array}$ \\
\hline 4. & $\begin{array}{l}\text { The products of me- } \\
\text { lioration }\end{array}$ & $\begin{array}{l}\text { In the melioration of tools, the results are clear and highly visible. In the me- } \\
\text { lioration of concepts, on the other hand, the results are not always externally } \\
\text { visible, but express themselves in indirect ways. }\end{array}$ \\
\hline 5. & $\begin{array}{l}\text { Evaluation of the me- } \\
\text { lioration }\end{array}$ & $\begin{array}{l}\text { This is a problematic stage because the skills are new and not sufficiently } \\
\text { recognized. It is therefore difficult to evaluate this stage. }\end{array}$ \\
\hline 6. & Continuity & $\begin{array}{l}\text { Examples of this aspect were rare, and they were significant criteria for the } \\
\text { completion of the process of melioration and its definition as future intelli- } \\
\text { gence. }\end{array}$ \\
\hline
\end{tabular}


demonstrate what melioration is about: The president of one of the most successful hightech companies in Israel - El-Rom, was once asked: Does El-Rom in its way to success imitate American technologies? What actually makes El-Rom unique and successful? He then answered: "In many aspects, El-Rom adjusted American technologies, and work procedures to the Israeli social and ethnic fabric. El-Rom has adapted manufacturing processes. That is, the company has innovated. People from all over the world are coming to see and learn from that innovation. We also help them innovate in their own way". (More examples can be seen online www.passig.com/pic/MeliorationEng)

At this point of time, we cannot predict with any certainty, what will be the hierarchy of skills that our graduates will be asked to master. It is, however, certain that some of the skills we were brought up to master are irrelevant to today's reality. Take for example memorization. There are worldwide generations of students that attended schools in the $50 \mathrm{~s}$ and $60 \mathrm{~s}$, who were forced to invest time and efforts to master techniques for faster and efficient memorization of poetry, mathematical tables, and entire chapters of books. It was believed that by being able to recite by heart prose you would have some advantage in your adulthood life, and in the work force. It was true then. It is not true anymore, however.

In this study, we asked to take a different approach in defining the goals of education with regard to thinking skills. We embraced the proactive approach, for a change, and engaged to identify beforehand what might be the skills needed in the future of our students attending secondary education. These skills, we believe, probably will become obsolete in the future. We need, therefore, to constantly engage in being proactive to identify the evolutionary nature of human intelligence.

\section{Discussion}

At the beginning of the 21 st century it is clear to most, even to conservatives like Hernstein and Murray (1994), the authors of "The Bell Curve", that only about ten percent of the successful people in the real world are predicted to succeed by the achievement tests. This issue is becoming more and more troubling to the various training systems - from elementary schools and universities to the employers who hire the graduates of those systems. A few studies have tried to address this issue so far. Sternberg (1997), in his book "Successful Intelligence", claimed, as early as the beginning of the 1980's, that day-today intelligence demands a broader range of talents than those measured by the accepted tests. The skills that we value the most in our school curricula are precisely those, which are of least value in life outside the school walls. Intelligence is not a person's ability to learn or think in the framework of familiar systemic concepts, but his ability to learn and think with new systemic concepts that are applied thereafter to the existing body of knowledge. Sternberg, therefore, suggested a search for a new approach to intelligence, with whose aid it would be possible to develop different, more relevant measurement tools.

Sternberg's approach to the examination of the essence of intelligence is expressed mainly in terms of the context in which the intelligence functions. He suggested a contextual framework for understanding intelligence. His contextual concept gave us a way 
out of the vicious circle, which confronted research on intelligence in the past. In the past, intelligence was defined as that which is examined by intelligence tests. This contextual concept of intelligence can also, in Sternberg's opinion, provide us with a view of the quality of intelligence, something that is so often neglected, even by the new theories.

Most of the research carried out, as early as the 1970's and 1980's, dealt with intelligence as part of the individual's internal world (Resnick, 1976; Sternberg, 1982). These studies provided a means of understanding intelligence in terms of the cognitive structures and processes, which contribute to it. They contributed nothing, however, to the understanding of the connection between the individual and the external world. If we conceive of intelligence, at least in part, as behavior adaptive to the environment of the actual world, says Sternberg, then it is impossible to understand fully the quality of intelligence without understanding how the actual world fashions that which is intelligent behavior in a given cultural and social context.

It is unnecessary to point out that his approach was an impractical one for the educational system. This was mainly because it was unable to give the educator clear measures with whose help it would be possible to work within a framework of a curriculum for helping students to progress. Aside from this problem, very little was done to develop measuring instruments that would reflect the contextual approach.

In the 1980's Glasersfeld (1995), the founder of Radical Constructivism, asked "How is our knowledge created, and how valid is it?" He maintains that epistemology becomes a search for ways and means used by intelligence for the construction of an orderly world from components plucked from a flood of experiences. His constructivism begins with the assumption that every cognitive action takes place within a world of practical experience, perceived through goal-oriented awareness. There does not necessarily have to be a tie between the "real" world and our experience, according to Radical Constructivism. We build our world of experience through cognitive processes such as comparison, the creation of things, and permanence, and thereafter we think of it as the independent world. What makes knowledge true is its ability to exist. What makes knowledge capable of existing is its suitability and use for different goals, especially when it enables us to explain, to control, and to predict our behavior. Later, Glasersfeld (1997) added to his previous thoughts and said that knowledge is the result of creative activity, and therefore can't be transferred to a passive receiver. Each person who receives it must build it up actively and individually. Even so, the learner may be guided in a general direction, and may have conceptual structures organized for him which will keep him from going in directions which his mentor feels are incorrect. Constructivism had some good days in the education system. They did not last long, however, principally because it was hard to measure achievements according to process, and not just according to results. The system always preferred shortcuts, which generally are not loyal to the truth.

In contrast, Gardner (1994), tried a more practical way by describing intelligence as including many kinds of intelligence. Thus, he found himself adding to his list a new kind or two of intelligence every year. Parkins (1990) suggested focusing on "soft" intelligence, which may be learned easily. Goleman (1995), unlike Glasersfeld and Gardner, based human intelligence on one simple (or so it seemed) factor: emotional intelligence. 
A group of researchers went beyond them all, and basing their approach on the work of Jung (1971), suggested the development of a taxonomy of intelligence called MBTI (Myers-Briggs Type Indicator), which describes 16 kinds of personality (Myers, 1962; Myers and Myers, 1980; Myers and McCaulley, 1985; Ring, 1998). MBTI makes many distinctions between personalities: extrovert vs. introvert, two perceptual functions - intuition and sensation, two judging functions - thinking and feeling, two ways of dealing with the external world - judging and perceiving, and more beyond these.

Grigorenko (1997) added two ways of treatment, in space and time. He maintains that it is possible to categorize people as abstract or concrete in their relation to space, and as continuous or random in their relation to time. Miller (1997) suggested a slightly different taxonomy which distinguishes between analytic vs. holistic individuals, objective vs. subjective, and emotionally stable vs. emotionally unstable.

What is common to all of these thinkers is that they all attacked the empire, which flew the flag of IQ, which ruled, and which has continued to rule by force for many years indeed. They all maintain that the phenomenon known as human intelligence is elusive and suspect, and refuses to adapt itself to our concepts (Harpaz, 1998).

The broad and colorful cloth woven of many approaches, on only a few of which we commented here, indicates that as the 21 st century begins we haven't yet learned to develop a simple scale of cognitive goals with whose help it will be possible to prepare the next generation for taking on the task of continuing to lead humankind.

Our point is that if this is the case, in a situation wherein we have no clear and accepted definition of intelligence, and the changes in everything around us are so deep and dynamic, we must try a different approach, which will be more relevant, at least for the educational system. This approach is not meant to be a new theory which explains what intelligence, cognition, or some other form of thinking is. In changing times, it is meant to give us more concrete cognitive goals, with whose help we will be able better to prepare our children for the many challenges which will confront them in the future at every turn. This is the only way in which the correctness of this approach will be measured. These goals will have to be formulated in terms of thinking or learning skills.

In order to do this we found no better way than to examine what will be expected of our children in the future, as reflected in the vast literature about the future, and to select from it definitions in the form of cognitive goals. We used the language of thinking skills, behavioral terms, and key words that will be able to lead us on the arduous journey needed if we are to provide our children with a better preparation for their future. Fortunately, the educational system already has a similar framework at its disposal, which, more than all the other theories, turns out to be especially practical in day-to-day educational activity, despite the more than a few limitations which many have found in it (Anderson and Krathwohl, 2001). We are referring to the taxonomy prepared by Bloom et al., which was already formulated in the mid-20th century.

We suggest the addition of a future layer to the foundations and advantages of Bloom's taxonomy, in the hope that it will advance schooling goals so that they will be relevant to our children's future. In all honesty, we were unable to find a theory that was simpler or more attractive for our goals than Bloom's taxonomy. This is because it is so much 
an integral part of the professional culture, and so familiar to the day-to-day, pedagogical language of the teacher. This article is the continuation of an attempt to refresh the taxonomy of Bloom et al. .

\section{Summary}

Many contend that IT has not made a great difference in education, since it was introduced two decades ago to the classroom. Likewise, the body of literature reporting on the improvement of cognitive skills facilitated with computer assisted learning barely mounts to its expectations. The debate on this issue has taken ground in various scientific gatherings in recent years. However, it occurred to us, the more we progressed with this study, that the reason for the poor results scientists are receiving worldwide from IT performance in classes might be explained by another reason. It might be because we have been trying to teach a baby to crawl with skateboards. It might be that IT could improve a different hierarchy of skills not listed in today's educational and cognitive goals. This study claims that IT is driving a much higher and sophisticated hierarchy of cognitive skills. Information Technology is challenging our broadly known hierarchy of skills. However, it is also providing us with ways to execute the potential embedded in it.

\section{References}

Anderson, L.W., and D. Krathwohl (Eds.) (2001). A Taxonomy for Learning, Teaching and Assessing: a Revision of Bloom's Taxonomy of Educational Objectives. Longman, New York.

Bloom, B.S. (1956). Taxonomy of Educational Objectives. Longmans, New York.

Borgmann, A. (1999). Holding on to Reality: the Nature of Information at the Turn of the Millennium. University of Chicago Press.

Ennis, R.H. (1981). Eight fallacies in Bloom's taxonomy. In C.J.B. Macmillan (Ed.) Philosophy of Education. Philosophy of Education Society, Bloomington.

Gardner, H. (1983). Frames of Mind: the Theory of Multiple Intelligences. Basic Books.

Gardner, H. (1999). Intelligence Reframed: Multiple Intelligences for the 21st Century. Basic Books.

Gardner, H., M. Krechevsky, R.J. Sternberg and L. Okagaki (1994). Intelligence in context: enhancing students' practical intelligence for school. In K. McGilly (Ed.), Classroom Lessons: Integrating Cognitive Theory and Classroom Practice. Cambridge, MA, Bradford Books, pp. 105-127.

Glasersfeld, E.V. (1995). Radical Constructivism: a Way of Knowing and Learning. The Falmer Press, London.

Glasersfeld, E.V. (1997). The incommensurability of scientific and poetic knowledge. Expanded Translation of a Talk Given at the International Congress on Science, Mysticism, Poetry and Consciousness. Instituto Piaget, Lisbon, April 1994. Last visited: October 2001. http: / /www . oikos . org/vGknowl . htm

Gleick, J. (1999). Faster: the Acceleration of just about Everything. Pantheon Books.

Goleman, D. (1995). Emotional Intelligence. Bantam Books, New York.

Grigorenko, E.L., and R.J. Sternberg (1997). Style of thinking, abilities and academic performance. Exceptional Children, 63 (3), 295-312.

Harkins, A. (1992). Knowledge Base Learning: Bridging Industrial Education to the Knowledge. Saturn Institute, St. Paul, Minnesota 55104.

Harpaz, Y. (1998). The Education of Thinking. The Branko Weiss Institute for the Development of Thinking, Publication No 14 (in Hebrew).

Hernstein, R.J., and C. Murray (1994). Bell Curve: Intelligence and Class Structure in American Life. Free Press. 
Higgins, J.M. (1995). Innovate or Evaporate: Test \& Improve Your Organization's IQ - its Innovation Quotient. New Management Publication.

Jung, C.G. (1971). Psychological Types. Bollingen Series XX. The collected works of C.G. Jung (Vol. 6), (H.G. Baynes, trans., revision by R.F.C. Hull). Princeton, NJ, Princeton University Press. (Original work published 1921).

Kennedy, P. (1993). Preparing for the 21st Century. NY Random House.

Kurian, G.T., and G.T. Molitor (1996). Encyclopedia of the Future. Macmillan Library Reference, Two volumes.

Miller, R. (1997). What are Schools for? Holistic Education in American Culture. 3rd ed. Brandon, VT, Holistic Education Press.

Myers, I.B. (1962). Manual: the Myers-Briggs Type Indicator. Palo Alto, CA, Consulting Psychologists Press. Myers, I.B., and M.H. McCaulley (1985). Manual: a guide to the Development and Use of the Myers-Briggs Type Indicator. Palo Alto, CA, Consulting Psychologists Press.

Myers, I.B., and Myers, P.B. (1980/1990). Gifts Differing (Special anniversary edition). Palo Alto, CA, Consulting Psychologists Press.

Nelson, B.K. (1981). Hierarchy, utility, and fallacy in Bloom's taxonomy. In C.J.B. Macmillan (Ed.), Philosophy of Education. Philosophy of Education Society, Bloomington.

O'Dell, C. (1998). If only We Knew what We Know: the Transfer of Internal Knowledge and Best Practice. Free Press.

Parkins, E.J. (1990). Equilibration, Mind, and Brain: toward an Integrated Psychology. Praeger, New York.

Passig, D. (1996). An Israeli model of a Networked Teachers' Training Center for implementation of information technology in curriculum development. In D. Benzie and Y. Katz (Eds.), Information Technology: Supporting Change Through Teacher Education. IFIP (TC3), Laxenburg, Austria.

Passig, D. (1998). A Taxonomy of Future Cognitive Skills. School of Education, Bar Ilan University, Israel (in Hebrew).

Passig, D. (2001). A taxonomy of ICT mediated future thinking skills. In H. Taylor and P. Hogenbirk (Eds.), Information and Communication Technologies in Education: the School of the Future. Kluwer Academic Publishers, Boston, pp. 103-112.

Perelman, L.J. (1992). School's out: Hyperlearning, the New Technology, and the End of Education. NY, W. Morrow.

Ring, B.P. (1998). Introduction to Personality Type and Personality.

http://members.tripod.com/ PersonalityInstitute/TypeTerminology.htm

http://members.tripod.com/ PersonalityInstitute/Myers-

Briggs TypeIndicator.htm

http: //members.tripod.com/ PersonalityInstitute/Personalityl.htm

Schwartz, P. (1999). The Long Boom: the Coming Age of Prosperity. Perseus Books.

Seddon, G.M. (1978). The properties of Bloom's taxonomy of educational objectives domain. Review of Educational Research, 48, 303-323.

Sterenberg, R. (1997). Thinking Styles. Cambridge University Press, Massachusetts.

Sternberg, R.J. (1985). Beyond IQ: a Triarchic Theory of Human Intelligence. Cambridge University Press, New York.

Sternberg, R.J. (1982). Hand Book of Human Intelligence. Cambridge University Press, Cambridge.

Sternberg, R.J. (1997). Successful Intelligence: how Practical and Creative Intelligence Determine Success in Life. Simon \& Schuster.

Tapscott, D. (1997). Growing up Digital: the Rise of the Net Generation. McGraw-Hill. 
D. Passig holds a PhD in futures' studies from the University of Minnesota, Minneapolis, USA. He is a director of the Graduate Program of Educational Technology at the School of Education, Bar Ilan University, Israel. He is teaching graduate courses on educational futures, future technologies, social systems theories, futures' methodologies, multimedia, and virtual reality. He is heading the Virtual Reality Lab. He has established the Virtual Reality Laboratories at the School of Ed, and is conducting research on various aspects of the human user learning interface of virtual reality and multimedia. A variety of the virtual reality worlds that have been developed for research can be accessed via his web site at: www $\cdot$ passig. com. 


\section{Ateities aukštesniojo mąstymo igūdžiu taksonomija}

\section{David PASSIG}

Futuristai pranašauja, jog per pora artimiausių dešimtmečiu pasaulio bendruomenè išgyvens dideles permainas dèl nepaprastai sparčios technologiniu naujoviu plètros, kurios pakeis šiuolaikinès visuomenès esminius bruožus (Tapscott, 1997; Wallace 1999; Borgmann, 1999). Pokyčiai apims visus gyvenimo aspektus (Gleick, 1999). Jie turès milžinišką įtaką visuomenei, darbui, kultūrai bei menui. Žmonèms teks arba pasikeisti, arba likti visuomenès gyvenimo paribiuose (Higgins, 1995). Jie turès nuolat taikytis prie niekad nesibaigiančiu pasikeitimu bei pasinerti i nuolat besitęsiančiu prisitaikymu paremtą gyvenimą. Todèl visiškai pagrissta manyti, jog šiandieninių mokymo įstaigụ absolventams bus reikalingi kitokie mokymosi ir pažinimo igūdžiai, turèsiantys atliepti tuos gilius pokyčius, su kuriais bus susidurta. Šiame straipsnyje aiškinamasi, kokie bus pagrindiniai ateities visuomenès požymiai bei siūloma atitinkama ateities pažintiniu igūdžių, turèsiančiu ateityje studentams užtikrinti sėkmę, taksonomija. Remiamasi Bloomo taksonomija, tačiau, norint geriau atspindèti ateities reikmes, jo kategorijos gerokai išplèstos. Straipsnyje siūloma į tradicini mokymą įtraukti ir papildomą pažintinį skyrių, pavadintą "patobulinimu" (anglu k. melioration), i ka, autoriaus isitikinimu, nèra kreipiama pakankamai dèmesio šiandieniniuose mokymo planuose.

Tobulinimo mokymosi igūdžiai tampa vis labiau ir labiau reikšmingi ateities mąstymui. Jie apima didžiają dali ateities intelekto savybiụ. Straipsnyje šie igūdžiai apibrèžiami šitaip: tai igūdžiai, apibūdinantys gebejjimą informacijos sraute atsirinkti reikalinga jos kieki ir pobūdi bei mokejimą tai taikyti sprendžiant problemas, kylančias ivairiose situacijose skirtingu laiku bei skirtingose vietose. Taip pat išskiriami du skirtingi tokio mokymosi gerinimo (tobulinimo) būdai: A. Informacijos, sąvoku, idejuu bei ižvalgu išgryninimas. B. Irankiu ir technologiju tobulinimas. Šie būdai suskirstyti i i šešias aiškiai apibrěžtas pakopas: originali intencija, retrospektyvi intencija, procesas, rezultatas, įvertinimas bei tęstinumas. 